\title{
Leachate Categorization and Surface Groundwater Contamination at Municipal Solid Waste Landfill of Ahmedabad, Gujarat, India
}

\author{
Hitendra J. Jani \\ Analytical Research Laboratory, Bharuch Enviro Infrastructure Ltd., Plot No. 9701-9716, GIDC, Ankleshwar, Bharuch District, Gujarat, \\ India
}

\begin{abstract}
As a developing country the protection of groundwater resources is extremely important in India. Landfills are a major source of water pollution. The filling for the disposal site in Ahmedabad, occurs at a distance of about 50 meters from Ahmedabad plant water intake. In addition, there are several holes are near the tip, which is used for drinking and domestic use. A sury of the composition of landfill leachate and groundwater contamination Ahmedabad performed Landfill, located on gyaspur vilde. Leachate championship to nine points of the landfill. Groundwater samples (ecollected using snekkeeffekt five positions. Ala fo find 0 Dthe seasonal variation of water quality in water wells nearby, guCG water samples in both wet and dry se Leacolo and groundwater were physically and chemically characterized. The easured parameters were $\mathrm{pH}$, sulphe nitrat nitrites, $(\mathrm{Pb}, \mathrm{Zn}, \mathrm{Ni}, \mathrm{Cr}, \mathrm{Co}, \mathrm{Fe}, \mathrm{Mn}$, and $\mathrm{Cu})$. The results showed thane landfill leachate was probably th of the alkaline $\mathrm{pH}$ is recorded. These results also sho that the significant number of welk contamimated

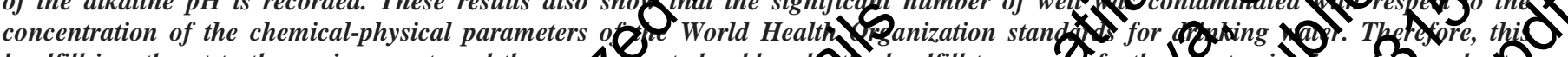

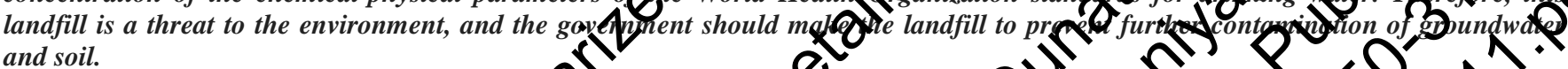

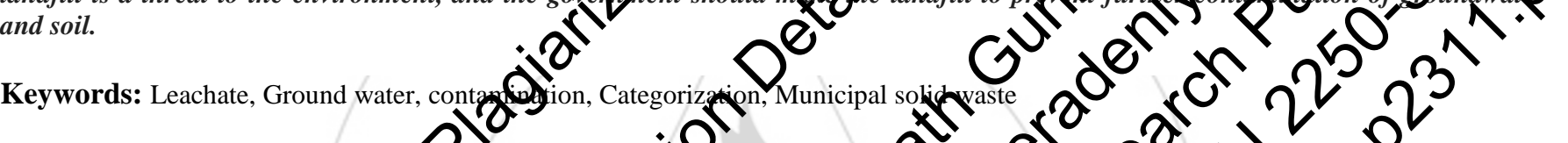
1. Introduction

India as a developing coun $\boldsymbol{D}_{\text {with limited }}$

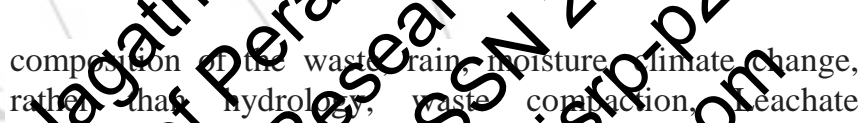

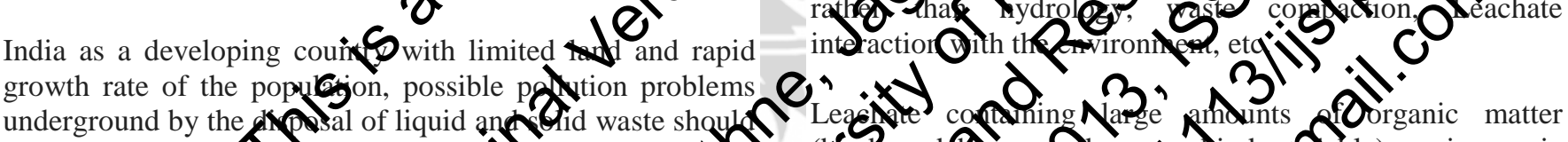

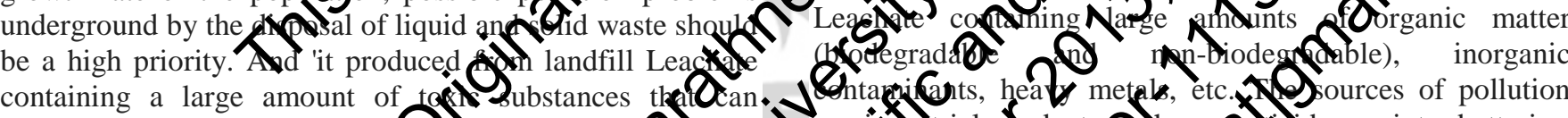

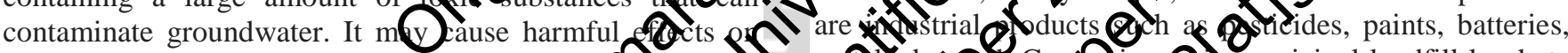

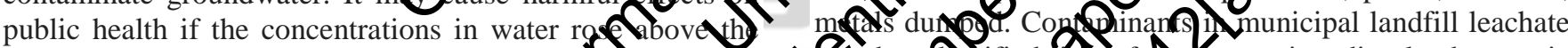

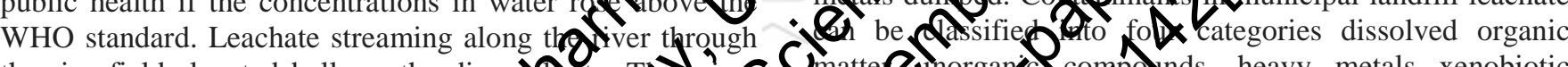
the rice fields located bellows the dispa 10 ite. bad smell around the place of waste procts. S(1) as is

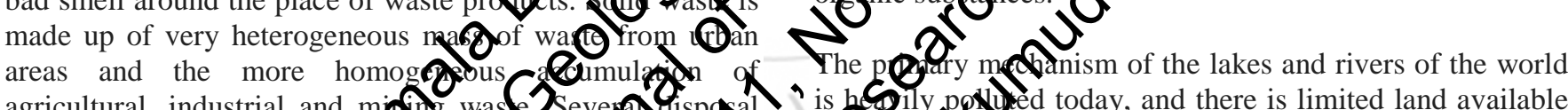

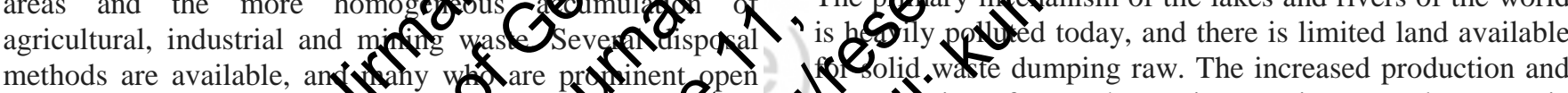

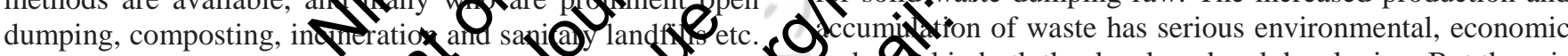
But the lack of land for landf sites and technofies a and dal in both the developed and developing. But there is other treatment options are dun 19 .

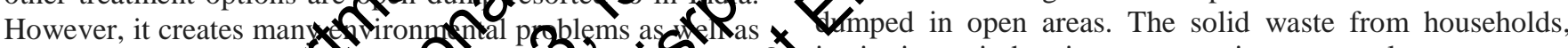
heath.

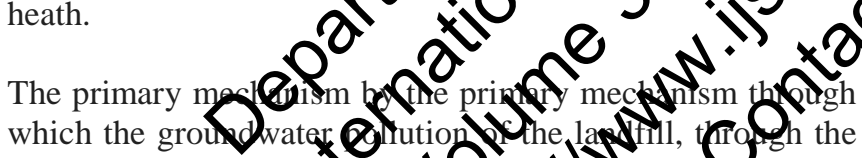

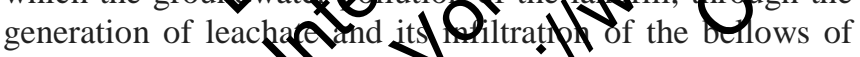
the water table. When landfill oerchate mixes with groundwater, it forms a plume theads in the direction of the water flowing. There are hiferent types of emissions from landfill gas emissions of volatile organic compounds, airborne particles and landfill leachate. Among these, landfill leachate is a major environmental problem in case of open waste dumps as landfill leachate is heavily contaminated with different types of pollutants. The

institutions, industries, etc. as important elements, trace elements, heavy metals and other chemicals it may be concentrated in these sites. Because of leaching of these substances, groundwater can be polluted up to grade nonacceptable. Landfills are sources of pollution of groundwater and soil pollution due to leachate and its trek through the waste. Leachate consists of high concentrations of natural chemicals that can contaminate groundwater and soil. Water is one of the essential materials necessary to sustain life and have long been suspected to be the sources of many of the diseases of the human being. It 'was just a little' more than a hundred years ago that evidence of disease transmission through water was established.
\end{abstract} composition of landfill leachate varies from time to time and one place to another because of differences in the 


\section{International Journal of Science and Research (IJSR) \\ ISSN (Online): 2319-7064 \\ Index Copernicus Value (2013): 6.14 | Impact Factor (2014): 5.611}

In the present study the effect of leachate seepage on groundwater quality was estimated by an unlined landfill in Ahmedabad, India. The various physical and chemical parameters including heavy metals and nutrients were analyzed in samples of leachate and groundwater for understanding the potential for groundwater pollution. It was also examined the effect of the landfill away from underground springs.

\section{Materials and Methods}

\section{Water Quality Analysis}

Can be caused by a landfill into groundwater ground water system samples from holes 5 to study the potential impact of leachate seepage to the groundwater in the area was water samples collected by Augur 5 points. Also known as detecting according to the quality of the water in the wells of the water, the water in the meantime, an example of both wet and dry.

Spectrophotometer was used to measure the concentratiof the method of the nitrate, nitrite, sulphate, plysphate samples of the application of the appropriate welength. Heavy metals Cd, Zn, As, Cr, Fe, Mn, Co, Ni 4 Pb of the samples was measured using aton absorption spectrophotometer (AAS). Use fla AAS atomic absorption spectrometry method of cal 140 n.

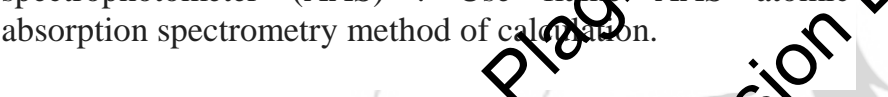

ion concentration. Leachate from a range of electric conductivity shows values. When the high value obtained L9 $22 . \mathrm{mS} / \mathrm{cm}$ minimum value is obtained when the value of $\mathrm{L} 1$ $8.9 \mathrm{mS} / \mathrm{cm}$. EC, however value for leachate that is not within the standard range of 0.7 to $4 \mathrm{Scm}-1$ treated wastewater discharges required by local standards. While the average value of conductivity $(13.36 \mathrm{mS} / \mathrm{cm})$ leachate effluent samples was to conclude that there was a high amount of mineral salt.

Table 2: Insitu and Nutrients parameters of the leachate

\begin{tabular}{|c|c|c|c|c|c|}
\hline $\begin{array}{c}\text { Sample } \\
\text { no }\end{array}$ & $\mathrm{pH}$ & $\begin{array}{c}\text { Conductivity } \\
\mathrm{mS} / \mathrm{cm})\end{array}$ & $\begin{array}{l}\mathrm{NO}_{3}^{-} \\
\text {In ppm }\end{array}$ & $\begin{array}{c}\mathrm{PO}_{4}^{-3} \mathrm{In} \\
\mathrm{ppm}\end{array}$ & $\begin{array}{c}\mathrm{SO}_{4}^{-2} \mathrm{In} \\
\mathrm{ppm}\end{array}$ \\
\hline L1 & 7.83 & 8.9 & 6.3 & 26.3 & 2 \\
\hline L2 & 8.12 & 19 & 9.9 & 26.7 & 21 \\
\hline L3 & 7.9 & 10.9 & 26.9 & 19.6 & 17 \\
\hline L4 & 8.13 & 15.9 & 8.3 & 25.5 & \\
\hline L5 & 8.2 & 13.8 & 10.6 & 0 & \\
\hline L6 & 7.97 & 16.8 & 33.2 & & \\
\hline L7 & 7.84 & 9.8 & 6.9 & & \\
\hline L8 & 7.44 & 2.95 & & & \\
\hline L9 & 8.41 & & & & \\
\hline
\end{tabular}

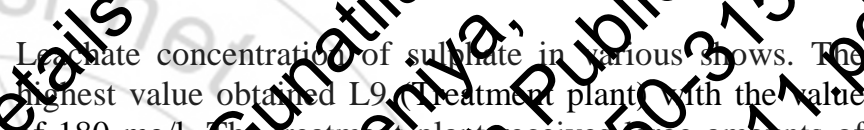

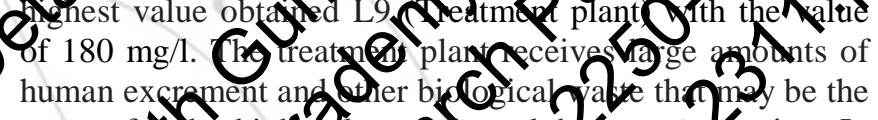

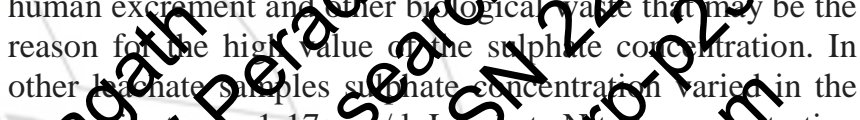

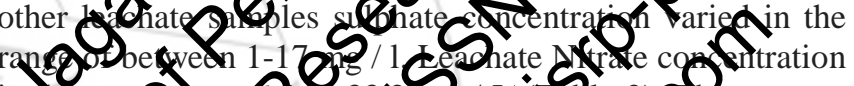

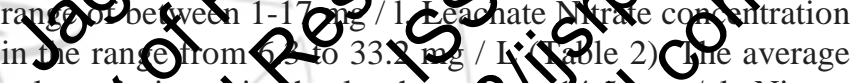

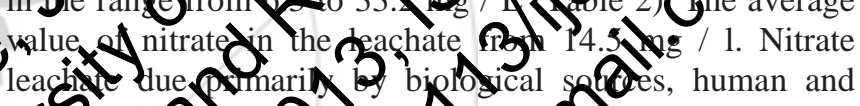
aryal exchent of pomething percentage of the

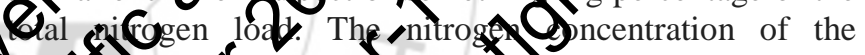
convind ingles thate pregres of extensive anaerobic bactural anities. Sudisente to nitrite is reduced to - Orite, pren cap quick 1 nd otherwise enjoy the food, ow, gather An No leachate concentrations higher thas itrate $\mathrm{N}$ trite. Hate shows varying concentrations d. posple. Whan wey get to a high value L5 $31.8 \mathrm{mg} / \mathrm{l}$, where of is least expensive is phosphate with L8

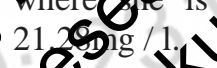

Leachate Analysis

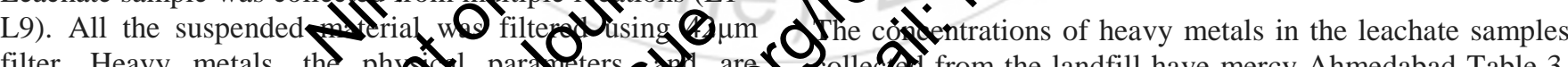

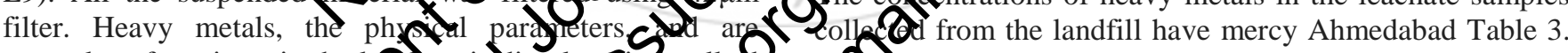

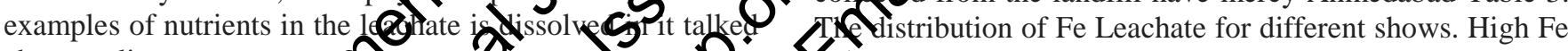
about earlier. $\quad$ CAtent of $9.2 \mathrm{mg} / 1$ leachate sample is measured by L4;

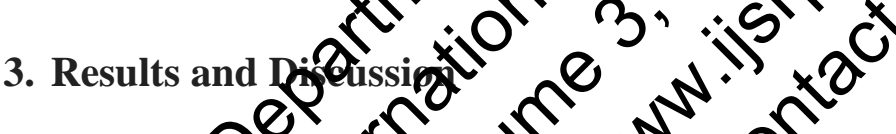 Characteristiceteactge} Leachate $\mathrm{pH}$ depend not ony thos aresent, but also with regard to which a partial pressur 202 that the intention of in a landfill leachate in contat with acids. This is the age of the landfill, leachate rain, and the composition of the most important factors is the type of waste issues. The average $\mathrm{pH}$ of the leachate in the sample is about 7.9; it can be concluded that the leachate is alkaline.

An indicator of dissolved inorganic species and the abundance of electrical conductivity is applied to the total where as the lower content of $1.18 \mathrm{mg} / 1$ measured by the L5. An L4 leachate sample indicates the highest level of Fe and Fe also scrap dumped in a landfill. Dark brown colour oxidation of ferrous to ferric leachate and the formation of ferric hydroxide complexes with Colloids and fulvic / humic substances.

Wastewater shows the distribution of Mn of between 0.27 to $2.91 \mathrm{mg} / 1$ and an average value of about $0.35 \mathrm{mg} / 1$. nine leachate concentration of $\mathrm{Zn}$ in the site are varied between 0.10 to $9.9 \mathrm{mg} / \mathrm{l}$. The presence of $\mathrm{Zn}$ in the leachate shows that the landfill receives waste from batteries and fluorescent lamps. The lowest concentration of a heavy metal to heavy metal $\mathrm{Pb}$ commemorated with a price range between 0.001 $0.031 \mathrm{mg} / 1$. The presence of $\mathrm{Pb}$ concentrations in the 


\section{International Journal of Science and Research (IJSR) ISSN (Online): 2319-7064}

Index Copernicus Value (2013): 6.14 | Impact Factor (2014): 5.611

leachate test does not indicate the disposition of $\mathrm{Pb}$ batteries, chemicals for processing photograph, $\mathrm{Pb}$-based paints and pipes landfill. The distribution of $\mathrm{Cu}$ in leachates showed different value. With the highest concentration of $13 \mathrm{mg} / 1$ measure sample L4 in which lower content of $0.08 \mathrm{mg} / 1$ measure L1. The high concentration of $\mathrm{Zn}, \mathrm{Cu}, \mathrm{Fe}$ and $\mathrm{Mn}$ reported in L4. On the other hand, most of these results are not the subject is within the standard of the wastewater can be cleaned for the issue of seeds, which are acceptable levels determined by international standards. $\mathrm{Cr}(0-0.31 \mathrm{mg} / \mathrm{L}) \mathrm{Ni}$ (0.07 to 0.76$)$ Co $(0.01-0.23 \mathrm{mg} / \mathrm{L})$, and in the leachate examples. A number of wastes dumped at the site Ahmedabad is likely to indicate the origin of $\mathrm{Zn}, \mathrm{Cr}, \mathrm{Cu}$ and $\mathrm{Ni}$ in the leachate.

Table 3: Heavy metals concentrations in leachate samples

\begin{tabular}{|c|c|c|c|c|c|c|c|}
\hline \multirow{2}{*}{$\begin{array}{c}\text { Sample } \\
\text { no }\end{array}$} & \multicolumn{7}{|c|}{ Element Concentration ( $\mathrm{ppm}$ ) } \\
\hline & $Z n$ & $\mathrm{Cu}$ & $\mathrm{Fe}$ & $M n$ & $\mathrm{Cr}$ & $\mathrm{Ni}$ & Co \\
\hline LI & 0.1 & 0.1 & 1.7 & 0.5 & 0 & 0.2 & 1.1 \\
\hline $\mathrm{L} 2$ & 0.5 & 0.3 & 18 & 0.6 & 0 & 0.8 & 0.2 \\
\hline L3 & 0.3 & 0.4 & 1.8 & 0.3 & 0 & 0.4 & \\
\hline L4 & 9.9 & 13 & 92 & 2.7 & 0 & 0.4 & \\
\hline L5 & 1.4 & 0.2 & 1.2 & 0.7 & 0 & & \\
\hline L6 & 0.8 & 0.4 & 5.2 & 2.9 & 0 & & 0 \\
\hline L7 & 0.7 & 0.2 & 4.6 & 1.5 & 0 & 0.1 & 0.2 \\
\hline L8 & 1.4 & 0.3 & 8.9 & 0.7 & & 0.1 & 0.2 \\
\hline L9 & 0.5 & 0.4 & 3.5 & & & 0.5 & 0.2 \\
\hline
\end{tabular}

\section{Groundwater Characteristics $\varnothing$}

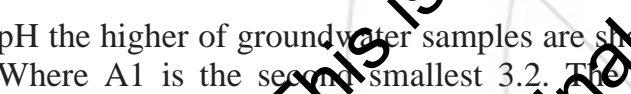$$
\sqrt{ }
$$<smiles>C1CCCCC1</smiles>

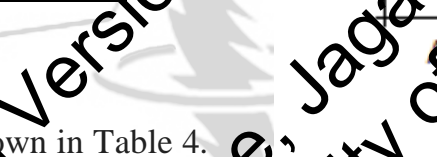

the cold period shows that the EC is higher than the sample collected dry period.

Table 4: Insitu parameters and Nutrients parameters of the Ground water samples

\begin{tabular}{|c|c|c|c|c|c|c|}
\multicolumn{7}{|c|}{ Ground water samples } \\
\begin{tabular}{|c|c|c|c|c|c|} 
Sample \\
no
\end{tabular} & $\mathrm{pH}$ & $\begin{array}{c}\text { Conductivity } \\
\mathrm{mS} / \mathrm{cm}\end{array}$ & $\mathrm{NO}_{3}^{-}$ & $\mathrm{SO}_{4}^{-2}$ & $\mathrm{PO}_{4}^{-3}$ & $\mathrm{NO}_{2}^{-}$ \\
\hline $\mathrm{A} 1$ & 3.2 & 2.3 & 25.3 & 110 & 0.72 & 0.296 \\
\hline $\mathrm{A} 2$ & 6.67 & 2.2 & 21.1 & 52 & 0.61 & 0.143 \\
\hline $\mathrm{A} 3$ & 6.99 & 1.4 & 5 & 11 & 0.33 & 0.1 \\
\hline A4 & 7.71 & 0.6 & 3.9 & 8 & 0.27 & 0.37 \\
\hline A5 & 7.86 & 0.1 & 2.3 & 3 & 0.07 & 0.023 \\
\hline
\end{tabular}
dump is an indicaton that should be under wate its effects on water quality. The

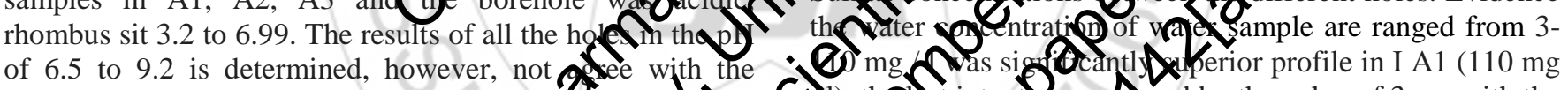

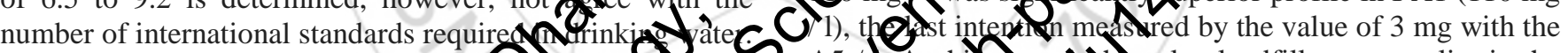
The $\mathrm{pH}$ of 5.19 to 6.96 in the middle of the wat a is not an extension of some of $10 \mathrm{~m}$ acgong $\mathrm{t}$.

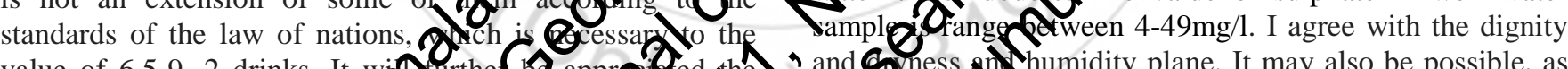

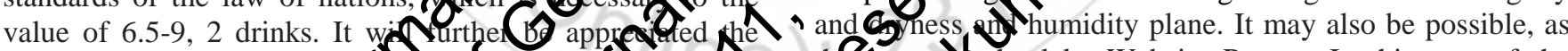

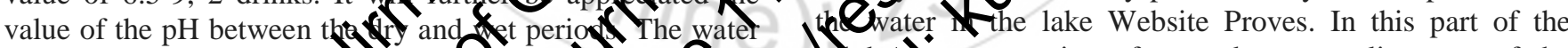

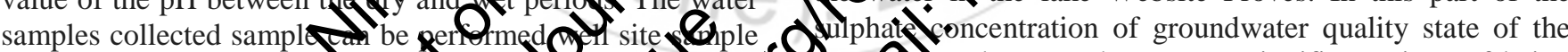

collected from this period sho lowe pH a not because they are no significant signs of being period.
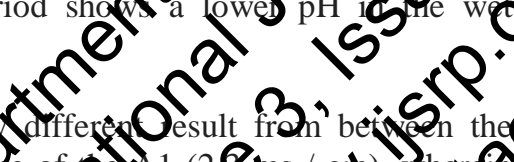

EC-values show a ver differesult fron beten the

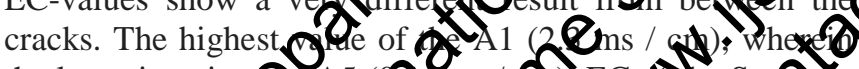
the least, is writte 1045 .

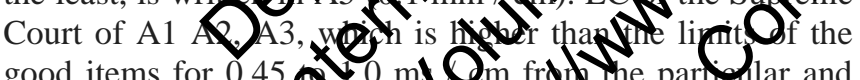

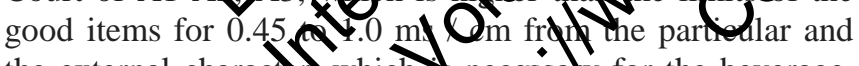
the external charactw, which neçaty for the beverage. These high values of conductivit $\mathbf{X}$ water under accession obtain an indication of the effect on the water. Amount of EC in the gaps in the inorganic pollution, is that there are not more than three days would remain as compared to the other holes. Location near a landfill due to free ions leaches from the waste. EC, however, are considered to be well within the standard range or water samples are bellow. Yes, it can be seen that the water samples conducted from drill site during
Aced to these things, he took water from the particular, bed the international order. Available in a variety of different forms of nitrogen in water and nitrogen, such as ammonia and oxidized nitrogen nitrite and nitrate. Nitrates in groundwater vary. The higher they are written in A1 when the value of $25.3 \mathrm{mg} / 1$, where the value of the smallest, are they not written in A5 with $2.3 \mathrm{mg} / 1$. Some researchers have reported an increase in the decomposition of nitrate in groundwater because of sewage dumped into the site disposal indicate the likely impact of leachate, which further supports the groundwater near the landfill is significantly affected by the leachate seepage. The concentration of nitrates in water samples is well within the range of 0.7 to $4.6 \mathrm{mg} / 1$. It will be understood that the value of the time between the dryness and moisture. The drilling location sample collected water samples can be performed period shows that the lower value of the sample collected after the 


\section{International Journal of Science and Research (IJSR) \\ ISSN (Online): 2319-7064 \\ Index Copernicus Value (2013): 6.14 | Impact Factor (2014): 5.611}

rainy Children coming period. The reason for the weight of leachate from on high what is the shift from a place in the way of the field of groundwater. The main PO4-3 measured by A1 with the value of $0.72 \mathrm{mg} / 1$ as the lowest concentration is measured by the value of A5 with $0.17 \mathrm{mg} /$ 1. Phosphate is less compared to the other, but the concentration of nutrients in the water. For less soluble phosphate and nitrate, in contrast low mobility, mainly converted to insoluble form and fixed in the ground. Phosphate, the contribution from the unprotected for servants mission excreta from septic tanks and sewage in which they were done most of the domestic detergent may have been out of phosphate powder, an animal in the desert. It is good with the examples of phosphate in the water concentration range between $0.09-0.24 \mathrm{mg} / 1$ and does not involve pollution conditions. The concentration of phosphate in the water sample is well between the range of 0.09 to 0.24 mg / 1. (Table 2). Although drilling site collected water samples can be performed dry period shows that the lower value of the sample collected after the rainy Childr coming period. The reason for this may be due increased leaching of the material by means of wich the rain and ground water in the process of the yo the ground. As they are released by the exant of the groundwater to rock $\mathrm{Fe}, \mathrm{Mn}, \mathrm{Co}, \mathrm{Cu}, \mathrm{Zn}, \mathrm{f}$ and $\mathrm{Ni}$. As. Until shown in table 4.9 .

Table 5: Heavy metal concentado in ground wate

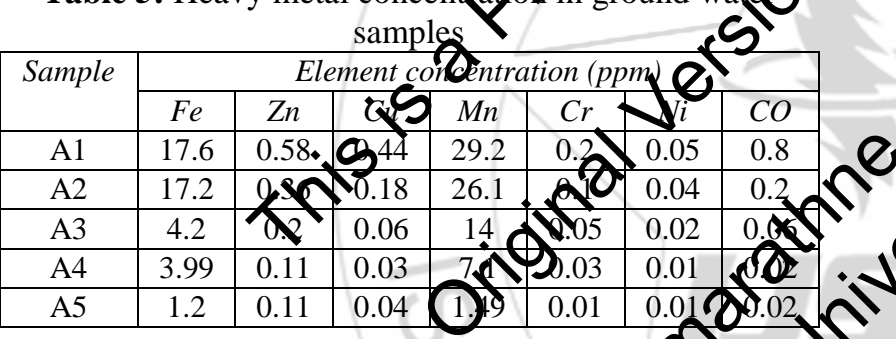

dump. The presence of Fe leads to water the colour of groundwater. Examples of Mn deficiency in the water far from the 1.49 to $29.2 \mathrm{mg} / 1$ in profile. How many $29.2 \mathrm{mg} / 1$ A1 is measured, which is measured by the A5 is the lowest 1.49 (Figure 2). This option is affected by the migration of leachate from the body dump. O Prince of the concentration of Mn A1 A2, A3, A4 are not acceptable, the level of the standard of the drink. Exceptional concentration of Mn was found to be valid, the most talented W4-site $2.85 \mathrm{mg} / 1$. In the wet season. The site is not within the standard of the Most High, he took water, the concentration of Mn in W4. But the concentration of Fe in the water, Is all well, who had the standard value. The worth of the manifest, and the dry and wet periods. It can be a good place to sample collected water samples conducted a dry period showed a lower value that sample is collected after the rainy Kids are coming period.

Z

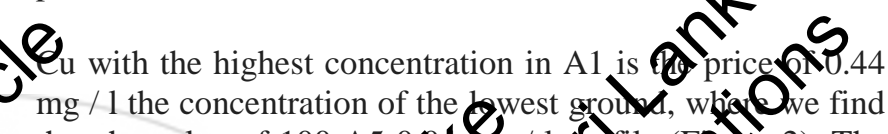
that the value of 100 A5 0.04 .

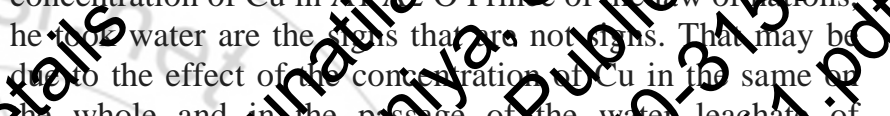
fie whole and in the passige of the yafe leaghat of

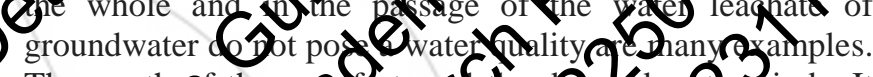
The worthor the morest, a the do kd wetperiods. It can be 8 ood oce to orple dellected per samples

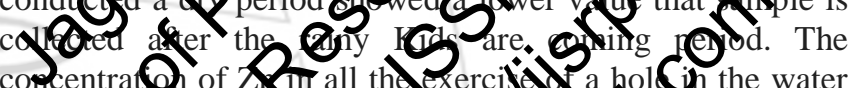

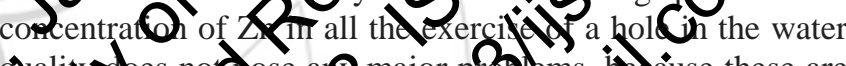
qualiudes no Dose apajor prolems datuse these are the osndards of accepable lave concen Qutions bellow to dok? Zn Qigh Noncention o $\$ .58 \mathrm{mg} / 50$ were measctur Ad, Wich nreasurestrowest concentration hont 0.10 , this is a good place to

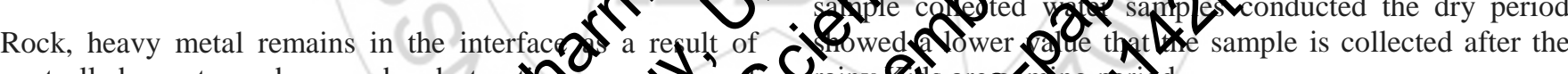
precipitation reactions. In addition, mbjity nom

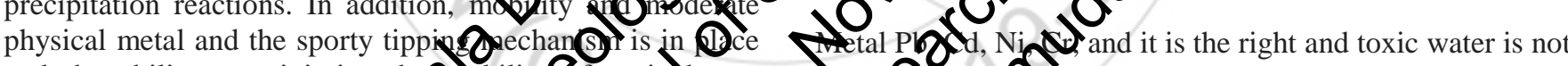

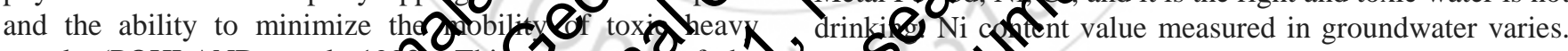

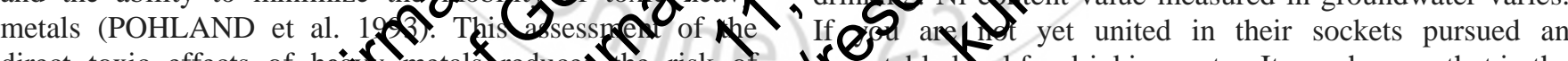

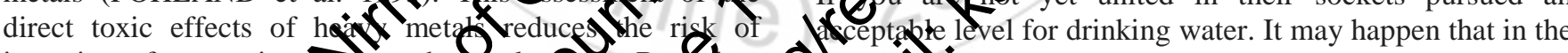

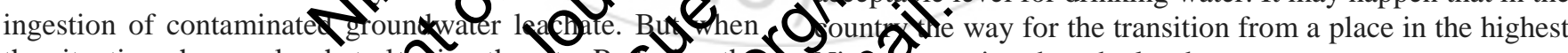
the situation changes leachate lofing the Re. Reging to Niplentration than the leachate. most powerful liquid formed aler manogen and coming into contacy the value of $\mathrm{Cr}$ with the highest concentration in $\mathrm{A} 10.2 \mathrm{mg}$

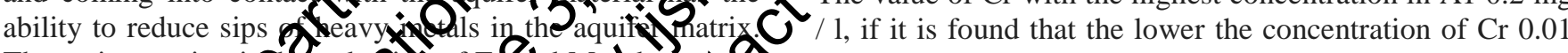
The main reaction is redug on of the appearance 80 propem. The fore, cadrentratios of these componet to ingase in sount th Cure of their proximate a tip arcan 19 a do setericity hazard. The example of the concentraticer far from the 1.2 to $17.6 \mathrm{mg} / 11$ profle (Table 5) which is above the lawful, as in the well, and found many examples. This option is affected by the migration of leachate from the body
A5 / 1. a high concentration of $\mathrm{Cr}$ in the A1 A2, A3 are not acceptable, the level of the quality of the beverage. It may be due to the effect of the borehole by means of the migration of leachate into groundwater. But $\mathrm{Cr}$ concentrations of all well water samples (with the exception of W4) within WHO, the default value. Although drilling site collected water samples can be performed dry period shows that the lower value of the sample collected after the rainy coming period. 

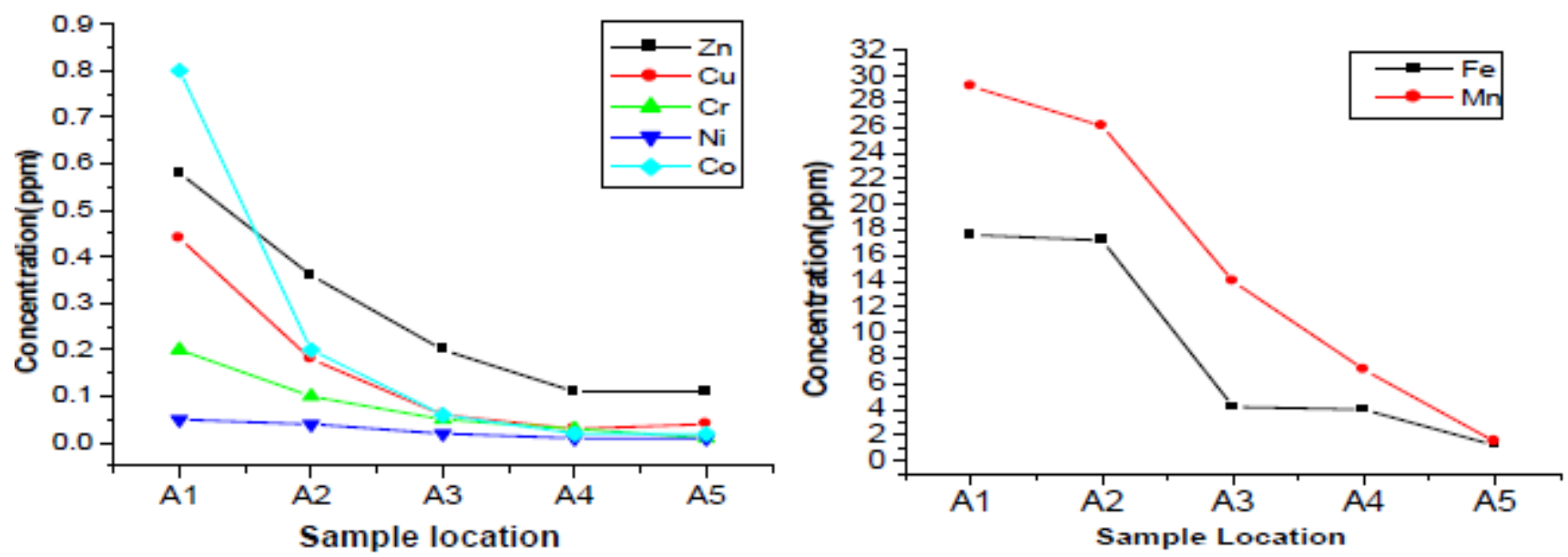

Figure 2: Variation of hegy metal along the profile

Table 6: Element concentrations of

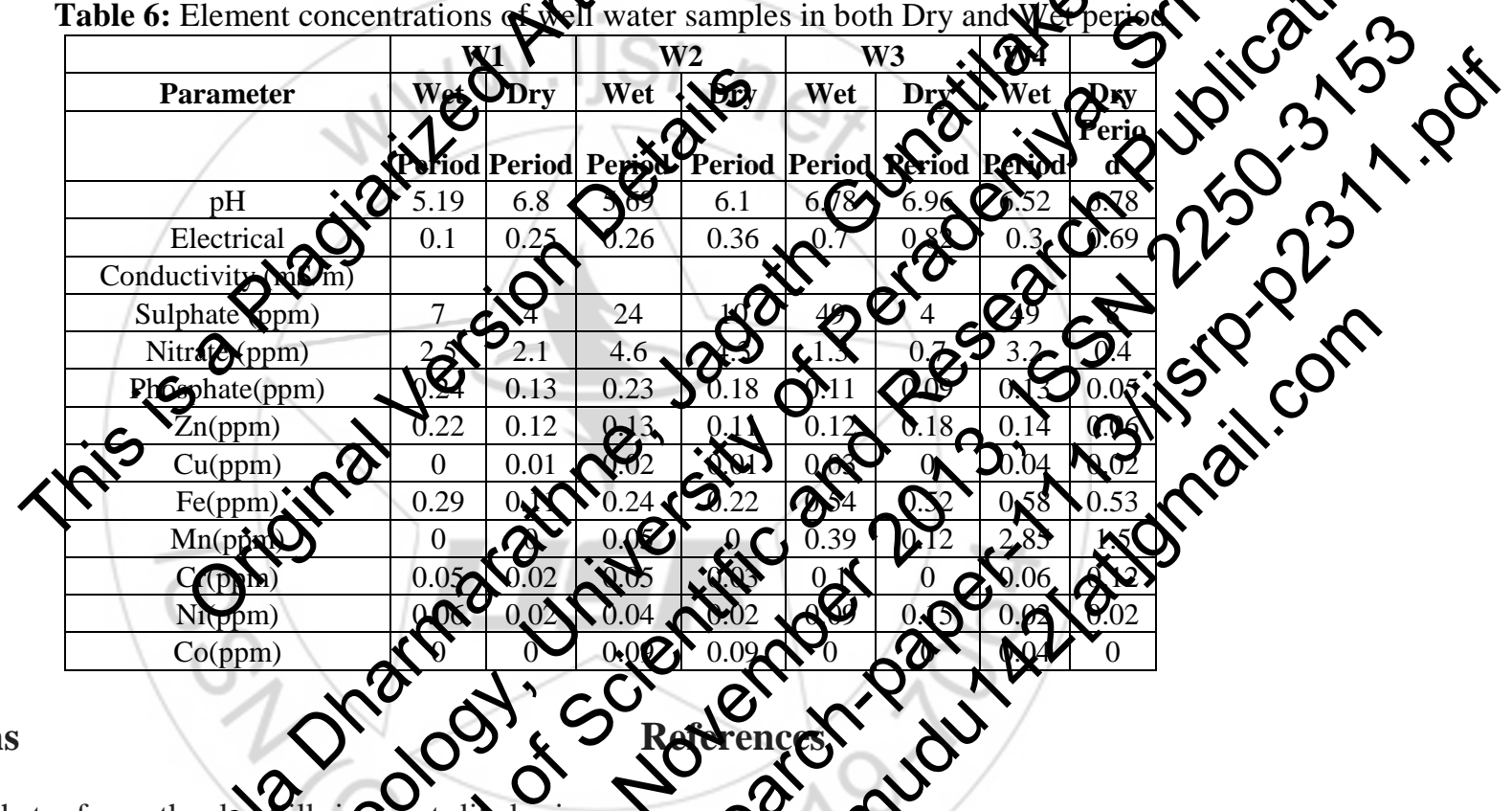

4. Conclusions

Ahmedabad leachate from the 20 .

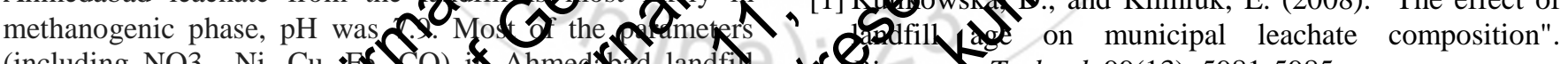

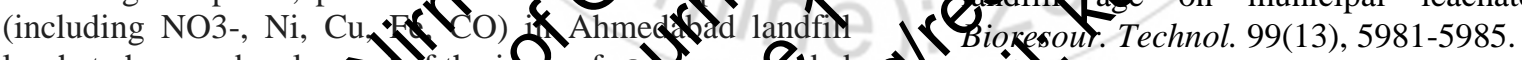

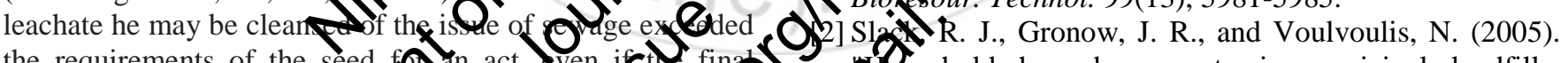
the requirements of the seed fan act, Jven ich fin

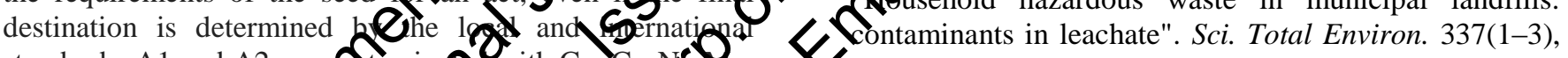

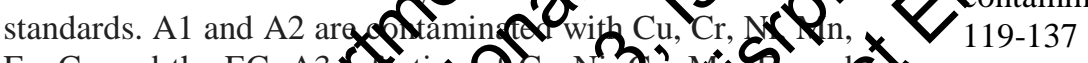

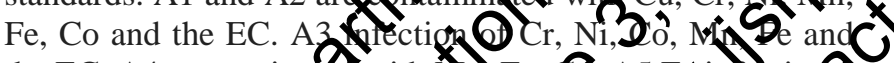
the EC. A4 contamigo with And he mease the ofmeter of the plehoce Omore than the sum of the the landfill. Improw the quaty of increased distance from the dum for any other reason for this is that there is a high cofentration of pollutants, has a significant impact on the quality of the leachate can be concluded that the groundwater close to the area, Ahmedabad landfill. Samples collected drought shows a lower concentration of elements and nutrients than samples collected after the rainy season. Because of the rain, flooded the leaching of the material.

[3] Umar, M., Aziz, H. A., and Yusoff, M. S. (2010). "Variability of Parameters Involved in Leachate Pollution Index and Determination of LPI from Four Landfills in Malaysia". International Journal of Chemical Engineering. 2010(6 pages).

[4] Jaskelevicius, B. and V. Lynikien. 2009. Investigation of Influence of Lapes Landfill Leachate on Ground and Surface Water Pollution with Heavy Metals. Journal of Environmental Engineering and Landscape Management. 17(3): 131-139.

[5] Asadi, M. 2008. Investigation of heavy Metals Concentration in Landfill Leachate and Reduction by different Coag ulants. In Proc. of 7th International Conference on Environmental Engineering. 484-488.

[6] Alkassasbeh, J. Y. M., Heng, L. Y. and Surif, S. 2009.

Volume 5 Issue 1, January 2016 www.ijsr.net 
Toxicity Testing and the Effect of Landfill Leachate in Malaysia on Behaviour of Common Carp (Cyprinus carpio L., 1758; Pisces, Cyprinidae). American Journal of Environmental Sciences. 5 (3): 209-217

[7] Pohland, F., Cross, W., Gloud, J., and Reinhart, D. (1993). "Behavior and assimilation of organic and inorganic priority pollutants co-disposed with municipal refuse." EPA/600/R-93/137a, Risk Reduction Engineering Laboratory Office of Research and Development, Cincinnati, $\mathrm{OH}$

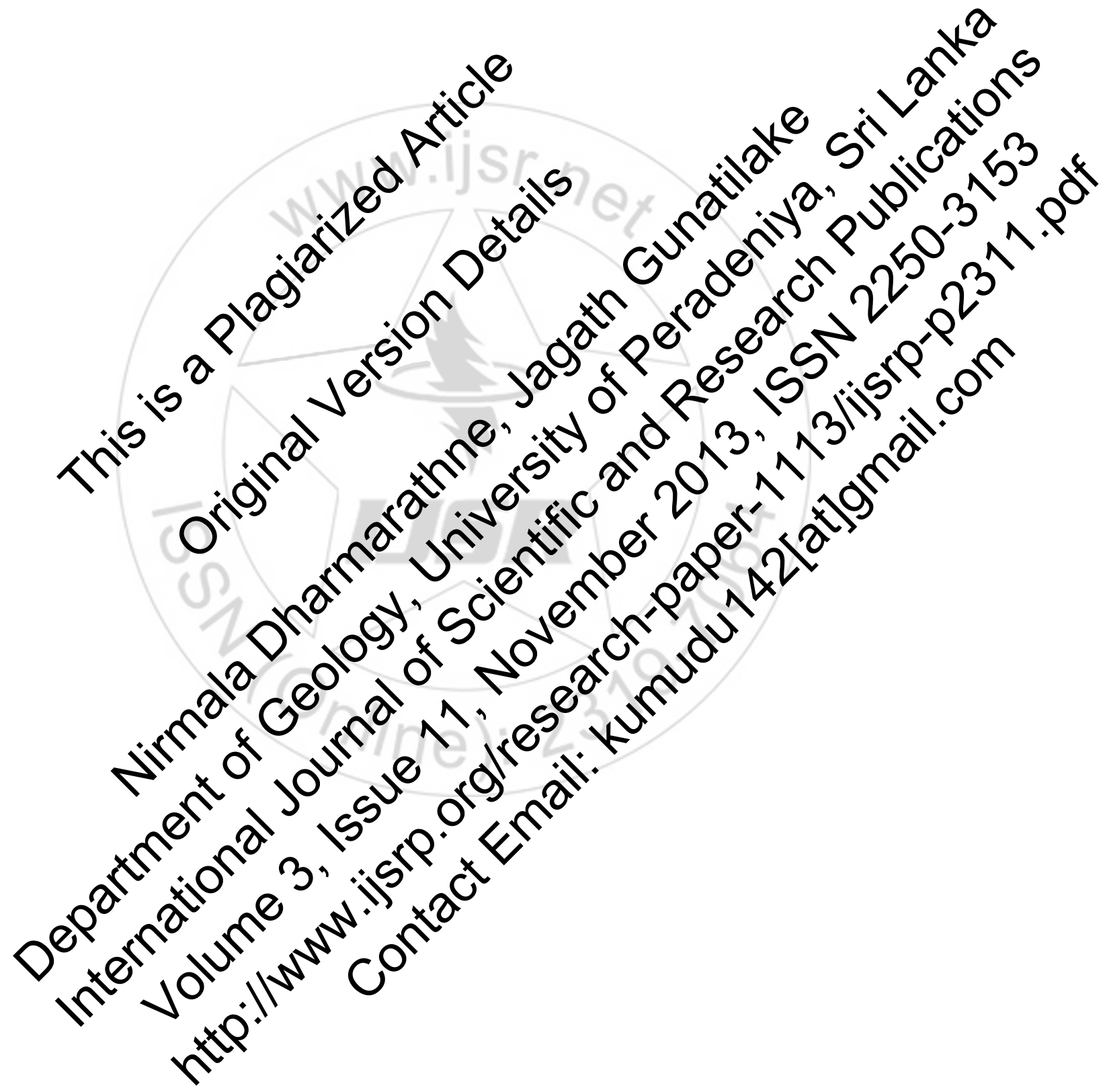

